AL-QANȚARA

XXXVII 1, enero-junio 2016

pp. $75-110$

ISSN 0211-3589

doi: 10.3989 /alqantara.2016.004

\title{
Moriscos en Antequera, 1569-1574
}

\section{Moriscos in Antequera, 1569-1574}

\author{
Rafael M. Pérez-García \\ Universidad de Sevilla
}

La guerra de Granada de 1568-1570 provocó la esclavización y/o deportación de la mayor parte de la población morisca del Reino de Granada. Este trabajo contribuye a explicar la situación de ésta en el periodo inmediatamente posterior al conflicto, estudiando el caso de la ciudad de Antequera y a lo largo de la frontera del antiguo Reino de Granada.

Palabras clave: Moriscos; Reino de Granada; Antequera; Esclavitud; Deportaciones.
The war of Granada between 1568 and 1570 caused that the majority of the morisco population of the Kingdom of Granada were enslaved and deported towards Castile. This article studies the history and characteristics of the morisco people who were settled in the city of Antequera and along the ancient grenadian frontier after the war.

Keywords: Moriscos; Kingdom of Granada; Antequera; Slavery; Deportations.

\section{El periodo 1569-1574 en la historia de los moriscos granadinos}

Los procesos de deportación y esclavización de los moriscos del Reino de Granada durante la guerra de $1568-1570^{1}$ produjeron la formación de numerosas agrupaciones de éstos en un buen número de poblaciones del Valle del Guadalquivir y también a lo largo de la frontera de los reinos de Jaén, Córdoba y Sevilla con el de Granada².

${ }^{1}$ Estudiados en su día por Vincent, "La expulsión de los moriscos del Reino de Castilla y su reparto en Castilla”, pp. 215-266, y en Domínguez Ortiz y Vincent, Historia de los moriscos. Vida y tragedia de una minoría, pp. 50-56.

2 Aranda Doncel, Los moriscos en tierras de Córdoba, para el Reino de Córdoba; Fernández Chaves y Pérez García, En los márgenes de la Ciudad de Dios. Moriscos en Sevilla, para el Reino de Sevilla, y por supuesto Lapeyre, Geografia de la España morisca, para una visión de conjunto. 
En esta frontera destacan los casos de Priego de Córdoba y Antequera, aunque éstas no serían sino nodos en una franja que arrancaría desde Gibraltar, Zahara, Teba, Ardales, Archidona, ... y llegaría al menos hasta Alcalá la Real ${ }^{3}$.

Este artículo estudia la evolución de la población morisca granadina en la ciudad de Antequera durante los años inmediatamente posteriores a la guerra, así como las distintas iniciativas políticas que a lo largo de ellos se suceden con el objeto de dar término a la estrategia de disgregación que no pudo culminarse a finales de $1570^{4}$. Como veremos, esta fase de decididas actuaciones de la Corona se prolonga hasta 1574-1575, con una serie de nuevos desplazamientos de gran volumen. Estos cinco o seis años constituyen un periodo claramente definido en el marco de una línea política que la Monarquía mantendrá hasta 1584, cuando se produce una nueva saca de moriscos del Reino de Granada y de las zonas fronterizas (incluyendo Antequera) que pretendía culminar quince años de extrañamiento de los moriscos de estos territorios, y que se saldó con un resultado bien decepcionante si atendemos a la ubicación y tamaño de las poblaciones moriscas en 1589 ó $1610^{5}$.

La documentación generada por la política de control fue extraordinariamente rica, y es ella la que nos permite acercarnos tanto a las características humanas de aquella población morisca tan castigada como a la historia de su reconstrucción como grupo social.

\section{Deportados y esclavos moriscos en Antequera, 1569-1571}

Por su emplazamiento a las puertas del Reino de Granada, en el cruce de los caminos que daban salida natural tanto a la Ciudad y Vega de Granada como al territorio malagueño hacia el valle de Guadalquivir y sus grandes urbes, la ciudad de Antequera fue testigo durante los años de la guerra del paso de las columnas de deportados moriscos y jugó

${ }^{3}$ Archivo General de Simancas (en adelante AGS), Cámara de Castilla (en adelante CC), leg. 2175.

${ }^{4}$ Vincent, "La expulsión de los moriscos", pp. 237-248.

${ }^{5}$ Lapeyre, Geografía de la España morisca, pp. 163-206; Fernández Chaves y Pérez García, En los márgenes, p. 213. 
un papel decisivo en la organización y acción militar en toda la zona occidental del viejo reino granadino. Por delante de ella pasaron en junio de 1569 moriscos de los sacados del Albaicín de Granada ${ }^{6}$, en marzo de 1570 los oriundos de la Axarquía malagueña ${ }^{7}$, y en noviembre de 1570 de buena parte del territorio correspondiente a la actual provincia de Málaga bajo la custodia de Arévalo de Zuazo, corregidor de Málaga ${ }^{8}$. Asimismo, la participación de las milicias de Antequera en el conflicto y su estratégica posición geográfica motivaron que centenares de esclavos moriscos, principalmente mujeres y niños, fueran introducidos en la ciudad en 1569 y 1570. A fines de este año, y durante los primeros meses de 1571, tras haberse realizado la primera fase de la deportación general, se produce la primera gran desbandada de deportados que intentan regresar o acercarse al Reino de Granada abandonando los lugares en donde habían sido depositados por los soldados y violando de modo generalizado las disposiciones regias que lo prohibían. Muchos de ellos vieron en Antequera un lugar interesante donde establecerse, pues en ella era posible combinar la inmediatez con el Reino de Granada, mantener lazos en él, al tiempo que no "volver" al mismo, al menos de un modo claro, como comportamiento menos arriesgado frente a las durísimas penas vigentes en esa materia. Finalmente, estos huidos se mezclaron en la ciudad con otros moriscos libres que en los meses anteriores se habían establecido en ella con permiso para ello. Con todos estos y diversos aportes, a mediados de 1571 se había formado en Antequera una minoría morisca que superaba ampliamente el millar de individuos.

A comienzos de octubre de 1571, Felipe II puso en marcha un nuevo proceso deportatorio que pretendía afectara a la mayor parte

${ }^{6}$ Fernández Chaves y Pérez García, En los márgenes, pp. 145-146.

${ }^{7}$ Fernández Chaves y Pérez García, En los márgenes, p. 149.

${ }^{8}$ El 6 de noviembre de 1570, Arévalo de Zuazo escribía al Rey explicándole cómo había sacado "los moriscos de la Sierra de Bentomiz y de todo el corregimiento y comarca" y el día 5 los había llevado a Antequera, "adonde habían llegado otros de los de mi comisión, y estarán juntos más de tres mill y ochocientos grandes y pequeños"; una parte de sus deportados deberían ser llevados a Écija y Carmona (Instituto Valencia de Don Juan, envío 1, f. 81; véanse también los ff. 79 y 80; en adelante se citará como IVJ). Del 29-I1571 es la interesante carta de Arévalo de Zuazo explicando el reparto final que realizó en Extremadura, dejando un reguero de enfermos por algunos de los lugares que atravesó: 135 en Córdoba, 75 en Guadalcanal, 82 en Medellín (AGS, CC, leg. 2157, f. 132). Para la historia y destino de los moriscos de la Axarquía, véase Bravo Caro, Felipe II y la repoblación del Reino de Granada. La taha de Comares. 
de la franja de territorio andaluz comprendida entre el río Guadalquivir y la frontera del Reino de Granada. La orden del Rey, de 2 de octubre de 1571, iba dirigida al Presidente de la Chancillería de Granada, y entre los motivos se recordaban el gran número de deportados que habían huido y regresado al Reino de Granada, algo fácil de hacer desde estas comarcas, así como el apoyo que prestaban a los rebeldes que resistían en las serranías. El objetivo final era que en este territorio sólo quedasen los moriscos esclavos, siendo desplazados los libres hacia el norte ${ }^{9}$. En relación directa con esta orden real, el día 10 de octubre el corregidor de Antequera dictó un auto en el que tras describir la realidad de los moriscos en la ciudad, se hacía eco del espíritu y letra de la orden real de 2-X-1571, y tomaba medidas para su pronta aplicación. Sus palabras no han perdido interés:

\begin{abstract}
"que por quanto después del levantamiento de los moriscos del reino de Granada han venido a esta ciudad muy gran número dellos e de presente están en ella ansí del Alpujarra como de la Xarquía de la ciudad de Málaga e Vélez y otras partes y se entiende que muchos dellos están sin orden alguna de su magestad y se han venido de las partes y lugares donde fueron dejados lo qual es contra los bandos que por orden de su magestad se han publicado después del dicho levantamiento y conviene que los culpados se castiguen y se proceda contra ellos conforme a los dichos bandos y nuevas provisiones y de estar tanto número de moriscos en esta ciudad se han seguido y siguen muy grandes inconvinientes porque por estar tan cercana esta ciudad a la sierra y reino de Granada los moriscos que se vienen de la tierra adentro tienen comodidad para ser receptados e encubiertos por los moriscos que aquí residen siendo como son libres y tienen sus casas y recogimientos adonde hordinariamente hay grandes consultas entre ellos y juntas y muchos dellos son inútiles a esta república y aun dan ocasión e causa que muchos de los esclavos moriscos cabtivos se vayan a la sierra como se han ido y
\end{abstract}

\footnotetext{
${ }^{9}$ Una exposición más detallada en Fernández Chaves y Pérez García, En los márgenes, p. 186. El texto de la orden del Rey de 2-X-1571, en AGS, CC, leg. 2161, f. 46. Las instrucciones y despacho para sacar a los moriscos de Alcalá la Real, Cabra, Lucena, Baena y Castro del Río, de 3-X-1571, señalando su traslado a Extremadura, en AGS, CC, leg. 2161, f. 63; para los asentados en Úbeda y Baeza, que serían repartidos por el área de Toledo-Madrid-Guadalajara, AGS, CC, leg. 2161, f. 64; los de los territorios andaluces de la Orden de Calatrava, de Jaén, Andújar, Écija y Osuna, a Castilla la Vieja (AGS, CC, leg. 2161 , ff. 65, 66, 67). Los moriscos de Espejo, Alcaudete, Montemayor y la villa de Priego fueron concentrados en Córdoba, aunque para ellos acabó allí su viaje por un cambio de planes (AGS, CC, leg. 2161, f. 69. Madrid, 11-XII-1571). Más información sobre esta deportación de los moriscos de Andalucía en el otoño de 1571, en AGS, CC, leg. 2161, ff. 70-74, y Vincent, "La expulsión de los moriscos", pp. 254-259.
} 
se entiende y tiene por cierto que no viven christianamente y conviene al servicio de nuestro señor y de Su Magestad e bien desta república que se entienda y sepa la orden e manera con que han estado y están los dichos moriscos libres y si tienen pasaportes o no"10.

Para poner fin a esta situación de descontrol, el corregidor don Fadrique Manrique ordenaba pregonar el domingo siguiente, día 14, que todos los moriscos libres deberían mostrar a las autoridades en el plazo de cuatro días las licencias que tenían para poder estar en Antequera (so pena de 200 azotes y seis años de galeras para los varones y de esclavitud para las mujeres), y a los dueños de esclavos moriscos que "declare cada uno en particular los moriscos que tienen y porqué título" en seis días tras el pregón y so pena de pérdida de los esclavos $^{11}$. El resultado fue inmediato. Entre los días 15 y 17 de octubre, 57 familias moriscas libres (de entre uno y ocho miembros, y que sumaban unos 180 individuos, entre los que abundaban los naturales de la ciudad de Granada y las personas de avanzada edad) presentaron sus pasaportes o recaudos; de otra treintena escasa de moriscos no consta que presentasen ningún documento acreditativo. Con estos datos, se procedió a realizar un registro o padrón de moriscos libres. Otro registro de moriscos, esta vez de los esclavos, se confeccionó el día 14 de octubre, con centenares de nombres ${ }^{12}$.

En realidad, el sentido último de estos alistamientos no era otro que disponer de las herramientas necesarias que permitieran controlar y, en su caso, trasladar a los moriscos fuera de Antequera. La orden de deportación fue dada por don Pedro de Deza, Presidente de la Chancillería de Granada, el 22 de octubre de 1571. En ella se aclaraba que "por culpa de algunos [moriscos] inquietos de mala vida que con ocasión de estar cerca [del reino de Granada] se han vuelto a la sierra son causa de que vengan a ser tenidos por sospechosos y merecedores de castigo los que por ventura están inocentes", y explicaba que los moriscos libres (hombres, mujeres y niños) serían trasladados a Castilla con el objeto de que pudiesen vivir tranquilamente (fuera del efecto perturbador de los "inquietos"), y que podrían "disponer de sus bienes

${ }^{10}$ Archivo Histórico Municipal de Antequera (en adelante AHMA), Fondo Municipal (en adelante FM), leg. 3298. Auto de 10-X-1571.

${ }^{11}$ AHMA, FM, leg. 3298.

${ }^{12}$ Ambos documentos en AHMA, FM, leg. 3298. 
muebles o llevarlos también consigo ... y porque puedan ir con más comodidad se les darán vagajes y carros en que lleven su ropa y familia..., y se les asegura que en sus personas y bienes no les será hecho ningun agravio ni molestia sino que serán bien tratados...”. En una complementaria Instrucción de lo que se ha de hacer en la ciudad de Antequera, se especificaba que "los esclavos no se han de sacar", y se daban normas de actuación para asegurar la buena marcha de la deportación, intentanto aprovechar la experiencia adquirida en las sacas del año anterior:

- enfermos e impedidos quedarán en la ciudad "alistados y entregados a la justicia";

- se les concentrará antes de la marcha y "se les hará una plática muy amorosa declarándoles la tierra y lugar adónde los llevan por obviar sus imaginaciones y para que vayan de mejor gana dándoles a entender que la mudanza es para mejor bien suyo... y que en el camino se les dará todo buen recaudo de bagajes y a los pobres bastimentos...";

- serán escoltados con una escolta suficiente que impida las fugas, y se pondrá guarda en los pasos por los que pasaren hasta cuatro o cinco días después de que los hubiesen atravesado, con el objeto de impedir su regreso; asimismo, se evitará entrar en "lugares grandes", para evitar que se escondan y porque "hurtan alli muchos moriscos y se les hazen muchos agravios y suceden inconvinientes" $"$.

Por fin, el 30 de noviembre de 1571 llegaron a Antequera las órdenes para sacar a los moriscos libres. Ese mismo día se pregonó en los lugares más emblemáticos de la ciudad el bando para sacar "todos los moriscos y mudéxares que en esta ciudad están y han venido a ella después del levantamiento del reino de Granada sean metidos la tierra adentro...". Por la tarde ya estaban concentrados en la cilla de la ciudad unos 220 individuos (lógicamente volvemos a encontrar entre ellos una mayoría de los naturales de la ciudad de Granada, aunque también había algunos de Alhendín, Monda, Coín, Istán, Montejaque, etc), y el corregidor ordenaba que se avisara a los que estaban dispersos por el ${ }^{13} \mathrm{La}$
$\mathrm{X}-1571$.

${ }^{13}$ La orden de deportación y la Instrucción en AHMA, FM, leg. 3298. Granada, 22Al-Qantara XXXVII 1, 2016, pp. 75-110 ISSN 0211-3589 doi: 10.3989/alqantara.2016.004 
término de la ciudad, en el campo, para que también fueran recogidos. Ante la inminencia de la expulsión, muchos moriscos alegan enfermedad $\mathrm{u}$ otras causas para tratar de evitarla, dando lugar a una serie de autos resueltos por el corregidor durante esos días ${ }^{14}$. El día 2 de diciembre, don Fadrique Manrique ordena que el médico Andrés Delgado revise a todos y cada uno de los moriscos susceptibles de ser expulsados, expidiendo un certificado a los que todavía no podían ser expulsados, en aplicación de la Instrucción de 22-X-1571. Finalmente, el día 4 de diciembre se juntaron las bestias y bagajes con que se sacó a los moriscos "libres" de Antequera el día 5 de diciembre de 1571 hacia el norte ${ }^{15}$. Teóricamente, a partir de esta fecha solamente habrían quedado en la ciudad los moriscos esclavos (la inmensa mayoría, por otra parte), aparte de los enfermos e impedidos y algunos exceptuados por uno u otro motivo. Es a esta población a la que nos es posible conocer con precisión gracias al censo elaborado en 1573.

\section{La población morisca en Antequera según el censo de 1573}

\subsection{Los censos de moriscos de 1573. El Registro de Antequera}

La política de control de la población morisca esparcida por la Corona de Castilla a consecuencia de la Guerra de Granada fue desarrollando una normativa específica con instrumentos que la pusiesen en práctica, máxime cuando enseguida se comprobó la fuga masiva tanto de esclavos como de deportados de los lugares donde habían sido depositados ${ }^{16}$. En Andalucía, en los años inmediatamente posteriores a la guerra, el problema de las fugas se cruzaba con el de

\footnotetext{
${ }^{14}$ AHMA, FM, leg. 3298. Entre los enfermos hallamos el repertorio que va desde la recien parida, el niño enfermo hasta el anciano en cama. Otros motivos alegados están relacionados con la utilidad o con las propias circunstancias vitales. Así, la morisca Beatriz Hernández dirá que ella cura y tiene "oficio de sacar motas de los ojos", y las autoridades de la ciudad le darán permiso para quedarse a ella, su marido y familia "y no sean osados de salir desta ciudad ni su término" por la "utilidad" que supone su presencia. María García obtendrá también autorización para permanecer en Antequera junto a su hija por llevar ya diez años viviendo en ella, y no tener nada que ver con las circunstancias del levantamiento.

${ }^{15}$ Toda esta documentación relativa a la expulsión de octubre-diciembre de 1571 de Antequera, en AHMA, FM, leg. 3298.

${ }^{16}$ Vincent, "La expulsión de los moriscos", pp. 254-257.
} 
los rebeldes que seguían luchando o causando daños desde ciertas zonas de sierra, a quienes se unían los huidos, o a quienes ayudaban los residentes en poblaciones cercanas al Reino de Granada ${ }^{17}$. Poner fin a esta situación bélica, de mayores dimensiones de lo que hasta el momento se ha considerado ${ }^{18}$, al tiempo que desarrollar la política de deportaciones más allá de lo realizado en el invierno de 1570-1571, motivó el nuevo plan de deportación de octubre de $1571^{19}$, así como la promulgación de las pragmáticas de 30-VII-1572, "sobre los moriscos menores del reino de Granada", y la de 6-X-1572 "sobre los moriscos del reino de Granada y la orden que con ellos se ha de tener" (pregonada en Madrid en 8-V-1573) ${ }^{20}$. Esta última ordenaba la elaboración en cada población de un libro que contuviese la lista y registro de todos los moriscos granadinos, libres y esclavos, presentes en ella, con sus datos personales. Al comienzo de dicho libro debía incluirse una copia de la Pragmática. Esta orden dio lugar a una serie de censos de población morisca de extraordinaria calidad, algunos de los cuales han llegado hasta nosotros ${ }^{21}$. En este trabajo queremos contribuir al conocimiento de la población morisca en la época inmediatamente posterior a la guerra presentando el censo que se elaboró en la ciudad de Antequera ${ }^{22}$. En ésta, la Pragmática de 6-X1572 no se pregonó hasta el día 28 de junio de 1573 . Una semana más tarde, el día 5 de julio, comenzó la presentación de los moriscos (normalmente por parte de las personas que los tenían a su cargo) ante las autoridades de la ciudad (el corregidor y un regidor) para proceder

${ }^{17}$ Fernández Chaves y Pérez García, En los márgenes, p. 194-197.

${ }^{18}$ Como ponen de relieve los trabajos de Valeriano Sánchez Ramos.

${ }^{19}$ Analizado en Vincent, "La expulsión de los moriscos", y Fernández Chaves y Pérez García, En los márgenes, pp. 186-194, para el Reino de Sevilla.

${ }^{20}$ Estas disposiciones legales han sido publicadas en La expulsión de los moriscos del Reino de Granada (pragmáticas, provisiones y órdenes reales), edición facsímil con una introducción de Francisco Izquierdo.

${ }^{21}$ Han sido estudiados los de Pastrana (Prieto Bernabé, "Los moriscos en Pastrana según el censo de 1573", pp. 269-282), Toledo (Martz y Porres Martín-Cleto, Toledo y los toledanos en 1561, pp. 9-11; y Rodríguez de Gracia, "Moriscos expulsados de Granada y 'avecindados' en Toledo", pp. 153-188), Córdoba (así parece desprenderse de la información proporcionada por Aranda Doncel sobre los moriscos en tierras cordobesas; utiliza también dicho censo cordobés Vincent, "¿Cuál era el aspecto físico de los moriscos?”, pp. 303-313), y Écija (Fernández Chaves y Pérez García, "Notas sobre la destrucción de las comunidades moriscas malagueñas y su reconstrucción en la campiña sevillana, 1569-1610”, pp. 121-139).

${ }^{22}$ Se conserva en AHMA, FM, leg. 3298. En adelante lo citaremos como Registro. 
a su registro, tarea que concluyó el 18 de agosto, si bien en septiembre se registraron un par de familias de moriscos libres que habían llegado a la ciudad procedentes de Sevilla y Osuna, y todavía en el mes de diciembre un amo "despistado" registró varios moriscos. La información que proporciona el registro de moriscos de Antequera de 1573 es extraordinariamente valiosa, si bien también pone de manifiesto, y muy explícitamente, la multitud de resistencias y ocultaciones que protagonizaron muchos habitantes de la ciudad con el objeto de conservar a los moriscos que tenían esclavizados. No en vano, la obligatoriedad de la presentación de los esclavos o administrados moriscos ante las autoridades permitiría a éstas llevar a efecto lo estipulado en la Pragmática de 30-VII-1572 acerca de la liberación de los moriscos esclavizados ilegalmente durante la guerra, pues recordaba la ilegalidad de la esclavización de los moriscos de paces, de los hombres menores de diez años y medio, así como de las mujeres menores de nueve años y medio. Por ello, muchos amos cristianos viejos intentaron eludir el registro, escondieron a sus esclavos o los trasladaron fuera de la ciudad ${ }^{23}$. No obstante, la validez de la información del censo de Antequera de 1573 está fuera de toda duda.

3.2. Los moriscos en Antequera en 1573: sexo, edad, status legal, situación real

El registro de Antequera de 1573 nos arroja un total de 843 moriscos, de ellos 491 mujeres (el 58,24\%) y 352 hombres $(41,7 \%$ ). Esta relación entre sexos con predominio femenino es la que encontramos habitualmente a lo largo y ancho de la Andalucía occidental que acogió a los moriscos granadinos expulsados de su Reino ${ }^{24}$.

${ }^{23}$ La cuestión de la esclavitud y administración de los niños moriscos ha sido tratada con cierta atención en trabajos de N. Cabrillana, A. Martín Casares, J. Aranda Doncel, F. Andújar Castillo y otros. Para todos ellos y un análisis global del problema, véase Pérez García y Fernández Chaves, "La infancia morisca, entre la educación y la explotación", pp. 149-186. En este trabajo, además, abordamos de modo específico el caso de los niños moriscos en Antequera y las estrategias de sus "amos" para conservarlos bajo su poder.

${ }^{24}$ Así en Sevilla (Fernández Chaves y Pérez García, En los márgenes, por ejemplo pp. 109 y 139), o en Córdoba (Aranda Doncel, Los moriscos en tierras de Córdoba, pp. 97-100). 
El registro de Antequera distingue cuatro situaciones legales al presentarnos a cada morisco: esclavo, libre, en depósito y en administración de un cristiano viejo. La administración del niño/a morisco encomendado a un vecino cristiano viejo era la situación que la legislación preveía para los menores cuya esclavitud estaba prohibida y también para adolescentes huérfanos o simplemente al servicio de un amo cristiano viejo; otras veces no era más que la denominación que eliminaba la consideración servil al adaptarse la situación previa de esclavitud efectiva a lo dispuesto por la legislación en torno a los moriscos menores. El depósito se confunde a veces con la anterior, aunque solía tratarse de una situación en la que se encontraban moriscos, también adultos, que habían sido puestos por alguna autoridad bajo la custodia de algún cristiano viejo por distintos motivos. Los datos respecto al status jurídico de los moriscos se presentan en la tabla 1, organizados a partir de las propias categorías utilizadas en el Registro.

TABLA 1

Situación jurídica de los moriscos en Antequera según el Registro de 1573

\begin{tabular}{|l|c|c|c|c|}
\hline \multicolumn{1}{|c|}{ Situación jurídica } & Hombres & Mujeres & Total & Total (\%) \\
\hline En administración & 9 & 13 & 22 & 2,61 \\
\hline En depósito & 11 & 16 & 27 & 3,20 \\
\hline Esclavitud & 172 & 351 & 523 & 62,04 \\
\hline Libertad & 160 & 111 & 271 & 32,15 \\
\hline Total & 352 & 491 & 843 & 100 \\
\hline
\end{tabular}

Sin embargo, las contradicciones del propio documento revelan que, a pesar de una apariencia según la cual una tercera parte de los moriscos son libres, en realidad, casi todos eran esclavos de hecho. En este sentido, no dejan lugar a duda las expresiones que llaman esclavos a muchachos que no podían serlo según la ley, las que confunden el status de esclavitud con el de administración o las órdenes del corregidor a numerosos vecinos para que no vendan ni trasladen a los niños y niñas que han presentado y de los que él mismo ha constatado de vista una 
edad inferior a la del límite de esclavización. Considerando la situación real en la que se encontraban aquellos moriscos en Antequera, y ateniéndonos a los que eran esclavos, estaban en administración y al servicio de amos cristianos viejos, obtenemos un índice de dependencia sobrecogedor (superior al 90\%), tal y como se muestra en la tabla 2. En ésta hemos considerado como libres solo a aquellos que realmente llevan una vida independiente de amos cristianos viejos.

TABLA 2

Situación real de los moriscos en Antequera en 1573

\begin{tabular}{|l|c|c|c|c|}
\hline \multicolumn{1}{|c|}{ Situación } & Hombres & Mujeres & Total & Total (\%) \\
\hline Esclavitud / Dependencia & 330 & 458 & 788 & 93,5 \\
\hline Libertad & 22 & 33 & 55 & 6,5 \\
\hline
\end{tabular}

La dependencia se refleja en el hecho de que casi todos los moriscos viven en las casas de los cristianos viejos que los han llevado a registrar, una consecuencia inmediata de una guerra brutal. En realidad, sólo algunos individuos y unas cuantas familias son verdaderamente libres. El resto, casi todos, no son sino una masa de esclavos y personas secuestradas que han sido arrastradas y amontonadas en Antequera, donde son explotados en todo tipo de trabajos, desde el servicio doméstico hasta el trabajo en el campo ${ }^{25}$.

La estructura por sexo y edad (tabla 3 ) de esta población morisca vuelve a reflejar el impacto devastador de la guerra, la sobremortalidad masculina juvenil y adulta y el rostro femenino, infantil y juvenil de la esclavitud y la dependencia, con unas cifras que vuelven a coincidir con lo habitual en el resto de Andalucía ${ }^{26}$.

${ }^{25}$ Cf. AHMA, FM, legs. 3292 y 3298.

${ }^{26}$ Así en Sevilla (Fernández Chaves y Pérez García, En los márgenes, p. 109), el conjunto de la actual provincia de Córdoba (Aranda Doncel, Los moriscos en tierras de Córdoba, pp. 97-120), o en Granada (Martín Casares, La esclavitud en la Granada del siglo XVI, pp. 238-239, donde aporta también datos similares para Jaén, Baza o Guadix). El caso de Guadix ha sido estudiado detenidamente por: Garrido García, "Guadix y su tierra durante el primer año de la rebelión de los moriscos (1569): guerra y esclavitud", pp. 73-108; Asenjo Sedano, "Trabajo, honra y esclavos en la Granada de los siglos XV/XVII", pp. 223-254; y especialmente en Garrido García, La esclavitud en el Reino de Granada en el último tercio del siglo XVI: el caso de Guadix y su tierra. Para Guadix y Baza, véase también Asenjo Sedano, Sociedad y esclavitud en el Reino de Granada s. XVI. 


\section{TABLA 3}

\section{Estructura por sexo y edad de la población morisca de Antequera en 1573}

\begin{tabular}{|l|c|c|c|c|}
\hline Grupos de edad & Hombres & Mujeres & Total & Total (\%) \\
\hline $0-9$ & 108 & 68 & 176 & 20,88 \\
\hline $10-19$ & 113 & 115 & 228 & 27,05 \\
\hline $20-29$ & 46 & 124 & 170 & 20,17 \\
\hline $30-39$ & 28 & 76 & 104 & 12,34 \\
\hline $40-49$ & 18 & 66 & 84 & 9,96 \\
\hline $50-59$ & 10 & 24 & 34 & 4,03 \\
\hline $60-69$ & 10 & 9 & 19 & 2,25 \\
\hline 70 y más & 4 & 0 & 4 & 0,47 \\
\hline Edad desconocida & 15 & 9 & 24 & 2,85 \\
\hline
\end{tabular}

Nota: Entre los de edad desconocida, al menos cinco eran niños/as y quince adultos/as.

La representación gráfica de estos datos es sobradamente elocuente:

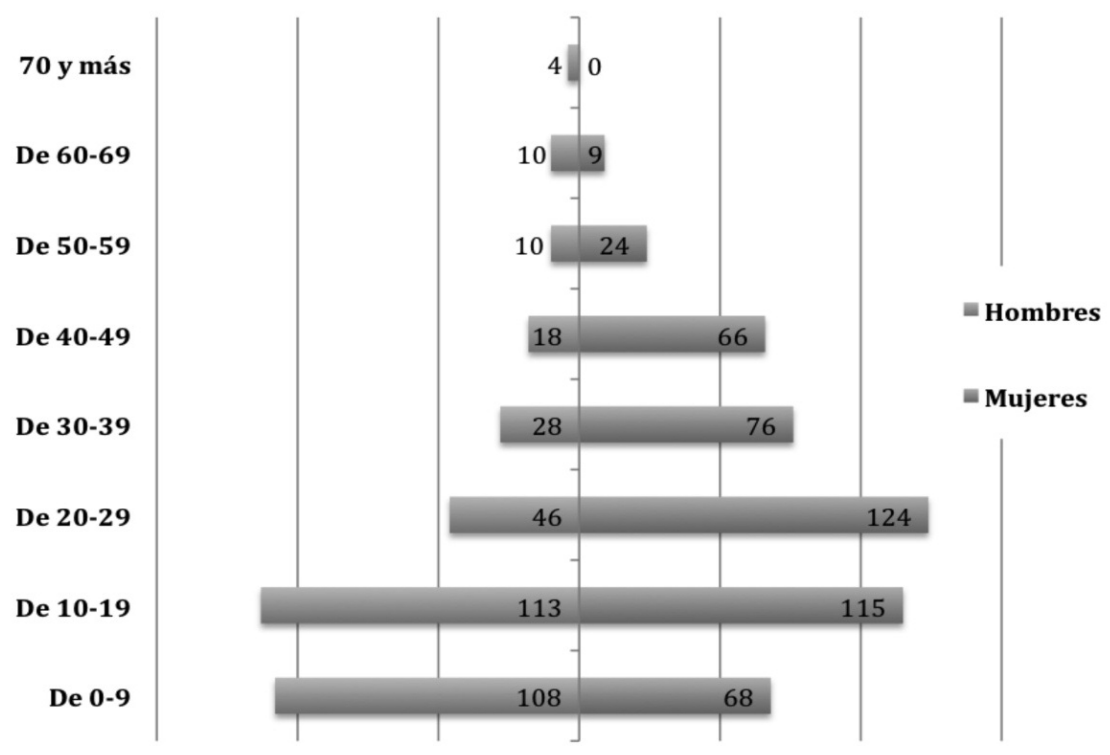

Al-Qantara XXXVII 1, 2016, pp. 75-110 ISSN 0211-3589 doi: 10.3989/alqantara.2016.004 
El desequilibrio entre el número de hombres y mujeres, así como la situación de esclavitud y dependencia, afectó en estos años, de nuevo como en el resto de la región ${ }^{27}$, a la capacidad reproductiva de la minoría. Si observamos al detalle el grupo 0-9 años (tabla 4), comprobamos la drástica reducción del número de nacimientos a partir del año 1570. Asimismo, llama poderosamente la atención el importante predominio masculino en el grupo de menor edad, en contraste y a la inversa de lo que sucede a partir de los 20 años $^{28}$.

TABLA 4

\section{El grupo de edad 0-9 años}

\begin{tabular}{|l|c|c|c|}
\hline \multicolumn{1}{|c|}{ Edad } & Hombres & Mujeres & Total \\
\hline 0 & 5 & 0 & 5 \\
\hline 1 & 2 & 3 & 5 \\
\hline 2 & 1 & 1 & 2 \\
\hline 3 & 6 & 3 & 9 \\
\hline 4 & 10 & 11 & 21 \\
\hline 5 & 19 & 12 & 31 \\
\hline 6 & 21 & 13 & 34 \\
\hline 7 & 17 & 13 & 30 \\
\hline 8 & 17 & 10 & 27 \\
\hline 9 & 10 & 2 & 12 \\
\hline TOTAL & 108 & 68 & 176 \\
\hline
\end{tabular}

Además, no deja de ser significativo que de los 10 niños/as de $0-1$ años, cuatro son hijos de padres libres, y sólo seis corresponden al grupo de población dependiente. La estructura por sexo y edad del segmento libre de la población morisca (tabla 5) no carece de interés, pues en ella, aún constatando la misma desproporción en la relación entre sexos, la distribución de los grupos de edad se corresponde mucho más con una forma piramidal "normal".

${ }^{27}$ Así para el caso de Sevilla (Fernández Chaves y Pérez García, En los márgenes, pp. 231-233).

${ }^{28}$ Y que quizás pueda explicarse en base a una preferencia de las madres por llevar consigo al hijo varón en la hora de la huida, o simplemente se trate de una peculiaridad local de este grupo. 
TABLA 5

\section{Estructura por sexo y edad de la población morisca libre en Antequera según el Censo de 1573}

\begin{tabular}{|l|c|c|c|}
\hline \multicolumn{1}{|c|}{ Grupos de edad } & Hombres & Mujeres & Total \\
\hline $0-9$ & 7 & 6 & 13 \\
\hline $10-19$ & 2 & 5 & 7 \\
\hline $20-29$ & 2 & 6 & 8 \\
\hline $30-39$ & 1 & 1 & 2 \\
\hline $40-49$ & 3 & 7 & 5 \\
\hline $50-59$ & 2 & 3 & 1 \\
\hline $60-69$ & -0 & 1 & 1 \\
\hline 70 y más & 1 & 0 & 8 \\
\hline Edad desconocida & 4 & 4 & 10 \\
\hline
\end{tabular}

Nota: De los ocho individuos cuya edad desconocemos, siete son adultos y solo uno de ellos un niño varón.

\subsection{Procedencia de los moriscos}

El estudio de la procedencia geográfica de los moriscos contribuye a explicar el perfil legal y demográfico del grupo morisco asentado en Antequera en 1573. En efecto, las elevadas tasas de esclavitud y dependencia, así como la ratio entre sexos, la sobremortalidad masculina o los desequilibrios entre los grupos de edades cobran sentido cuando observamos que la inmensa mayoría de ellos proceden precisamente de las comarcas del Reino de Granada que han sido más castigadas por la guerra, las cuales a su vez presentan un amplio paralelismo con las de mayor población y densidad morisca antes del conflicto $^{29}$. Por ello, casi no encontramos en Antequera moriscos oriundos de las zonas de escasa población morisca antes de 1568 (como las Siete Villas o la tierra de Alhama) o de aquellas otras de mayoritario poblamiento morisco pero de donde fueron sacados antes de que se

${ }^{29}$ La distribución de la población morisca por el Reino de Granada puede seguirse en Vincent, "Economía y sociedad en el Reino de Granada", pp. 183-186, y del mismo: "Los moriscos granadinos: ¿una frontera interior?", pp. 163-185, con datos por comarcas y poblaciones. 
rebelasen y fuesen deportados hacia el valle del Guadalquivir y el interior de Castilla (como ocurrió en la Axarquía en marzo de 1570 o en la ciudad y vega de Granada entre 1569 y $1570^{30}$ ). Además, casi la mitad de los moriscos originarios de Granada y su vega que se hallan en Antequera son precisamente personas libres ${ }^{31}$.

La mayoría de los moriscos presentes en la ciudad han sido traídos desde las Alpujarras granadinas y almerienses (212 incluyendo el Valle de Lecrín, y 139 respectivamente) y la Sierra de Bentomiz (105 individuos), escenarios primarios de la guerra. Otros espacios como el marquesado del Cenete, arrasado al comienzo de la guerra y cuyos moriscos fueron esclavizados masivamente ${ }^{32}$, o la tierra de Baza y Huéscar (con el dramático asedio de Galera) y el río de Almanzora, que sufrieron la decisiva ofensiva de don Juan de Austria durante los primeros meses de 1570, aportan contingentes notables, pero de una cuantía significativamente menor: en 1573 hallamos en Antequera 20 moriscos procedentes del Marquesado del Cenete, 17 del río de Almanzora y sólo 9 de la tierra de Baza (de los cuales, cuatro de Galera). Sin duda, en ello tiene mucho que ver la participación o no de tropas antequeranas en los distintos hechos bélicos, así como las direcciones adoptadas por los flujos del tráfico esclavista.

Respecto a las tropas antequeranas, desde los primeros días de la guerra las encontramos en la ciudad de Granada contribuyendo a su guarda junto con las milicias de otras partes de Andalucía ${ }^{33}$, participando en la ofensiva del marqués de Mondéjar que arrasa las Alpujarras en el primer trimestre de $1569^{34}$, y en diversas acciones tanto en las Alpujarras como en el Cenete y otras zonas de la provincia de

${ }^{30}$ Para estas deportaciones, Domínguez Ortiz y Vincent, Historia de los moriscos, pp. 50-56, y Fernández Chaves y Pérez García, En los márgenes, pp. 142-160.

${ }^{31}$ En concreto, de los trece moriscos de la ciudad de Granada, ocho son libres. En el caso de la Vega de Granada, son cinco los libres respecto a un total de quince. En suma, el $46,4 \%$.

${ }^{32}$ Ruiz Pérez, "El levantamiento morisco en tierras de señorío. El caso del marquesado de Cenete", pp. 291-336. En el Cenete se habrían capturado unos 2.000 moriscos, la mayoría mujeres y niños (Garrido García, "La esclavitud en el reino de Granada y la rebelión de los moriscos", pp. 51-52), de los cuales todavía quedaban más de 780 en Guadix en noviembre de 1569 (Asenjo Sedano, Sociedad y esclavitud, pp. 326-336).

${ }^{33}$ Fernández Chaves y Pérez García, En los márgenes, p. 60.

${ }^{34}$ Así, diversos vecinos de Antequera venden en ella en marzo de 1569 a mujeres y niños/as moriscos capturados durante su permanencia en el ejército del marqués en Jubiles, Ugíjar, el Fondón de Andarax, etc. (AHMA, Fondo Notarial (en adelante FN), leg. 1122, ff. $79,81,83,132,419$, etc.). 
Granada durante todo el transcurso de la guerra ${ }^{35}$. Asimismo, también hubo alguna unidad militar de Antequera en el área de Almería, concretamente la compañía del capitán don Fernando de Narváez (miembro de una destacada familia de la oligarquía local), que sirvió en $\mathrm{Adra}^{36}$, y que desde luego realizó la función de "puente" para el trasvase hacia Antequera y la zona de Málaga de parte de los gigantescos contingentes de moriscos esclavizados en el área almeriense $\mathrm{e}^{37}$. Ni que decir tiene que otros esclavos moriscos fueron llevados a Antequera por vecinos de distintas partes del Reino de Granada venidos a la ciudad a vender su mercancía ${ }^{38}$ o fueron comprados por antequeranos a soldados aquí y allá ${ }^{39}$.

${ }^{35}$ En marzo de 1570, por ejemplo, encontramos en el ejército con el que el duque de Sesa recorre la Alpujarra a don Jorge Morejón, vecino de Antequera, con una unidad de caballería a su cargo (Mármol Carvajal, Rebelión y castigo, p. 229). O en septiembre del mismo año, en la última entrada decisiva en la Alpujarra, hallamos al corregidor de Antequera, don Fadrique Manrique, al frente de las milicias de la ciudad en el seno de un ejército que también actuará en el Cenete (Mármol Carvajal, Rebelión y castigo, pp. 262-263).

${ }^{36}$ La noticia procede de AHMA, Actas Capitulares (en adelante AC), libro 1602. Cabildo de 19-II-1574. Don Fernando de Narváez habría sido comandante de la fortaleza de Adra (Tapia, Historia de la Baja Alpujarra, p. 272).

${ }^{37}$ De los que son simples muestras los enormes frutos de las cabalgadas efectuadas por las tropas en la zona (Cf. AGS, Contaduría Mayor de Cuentas, $1^{\text {a }}$ época, legs. 689 y 1846, por ejemplo). El mercado de esclavos moriscos de Almería durante la guerra ha sido estudiado por Cabrillana, Almería morisca, pp. 269-310. No se olvide que el puerto de Adra jugó un papel capital como base de las galeras que transportaban a los tercios que intervinieron en distintas operaciones anfibias en el transcurso de la guerra, así como punto de partida desde el que penetrar en las Alpujarras (cf. Tapia, Historia de la Baja Alpujarra, pp. 263-275), hechos que la convirtieron ineludiblemente en un importante centro de redistribución de esclavos moriscos. De 1-IV-1571 conocemos una relación del capitán Diego Gasca en la que explica cómo sirvió durante la guerra en Adra con su compañia de a caballo de guardas viejas, haciendo numerosas cabalgadas en las que cautivó muchos moriscos: de ellos sacaba el quinto real y el resto lo repartía entre él y sus soldados, enviando los esclavos a Málaga (AGS, CC, leg. 2157, f. 262).

${ }^{38}$ Como Pedro de Alcalá, vecino de Adra y estante en Antequera, que vende al regidor don Fernando de Narváez un esclavo morisco (García Garavit, de 30 años) natural de Júbar (en la taha de Ugíjar) (AHMA, FN, leg. 1185, f. 369r-v. 8-IV-1571). Llama la atención que en 1573 este regidor ya no tenía en su poder a este esclavo, pero sí a otras tres esclavas moriscas, dos de las cuales eran oriundas de Las Guájaras, en la tierra de Salobreña (Registro, ff. 29 y 35). Si este don Fernando de Narváez es el mismo que el que comandaba la compañía en Adra, lo cual es prácticamente seguro, habría aquí otra relación digna de considerar.

${ }^{39}$ Por ejemplo, Miguel Sánchez Vallejo, registraba en Antequera el día 5-VII-1573 a un esclavo morisco de 19 años llamado Diego y natural de Itrabo, en la tierra de Almuñécar, el cual lo había comprado a un soldado de Casabermeja "que lo ovo e captivó en el fuerte de las Guájaras altas" (Registro, f. 51). 
La propia situación de Antequera en el límite norte del territorio malagueño explica el peso relativamente importante representado por los moriscos de esta zona, que supera el $25 \%$, tal y como mostramos en la tabla 6. Es un porcentaje alto, aun teniendo en cuenta que los almerienses pasan del 23\% y los granadinos del $35 \%$, si consideramos la distribución de la población morisca antes de 1568 (según Bernard Vincent, en 1561 sería así: 13,7\% en la provincia de Málaga, 19\% almerienses, $67,3 \%$ granadino ${ }^{40}$ ). Por otra parte, el fenómeno de una presencia dominante o significativa de moriscos del área próxima en un determinado núcleo-mercado urbano es, aparte de perfectamente comprensible, común a otros centros conocidos. En Almería, los esclavos moriscos vendidos proceden fundamentalmente del territorio de su actual provincia, de casi todas sus poblaciones ${ }^{41}$, y en la ciudad de Granada, con un mercado de esclavos moriscos entre 1569-1571 con señalado carácter redistribuidor hacia fuera del Reino ${ }^{42}$, se vendieron principalmente moriscos procedentes del Valle de Lecrín, Alpujarras y río de Almería, marquesado del Cenete y río de Almanzora, con una ausencia casi absoluta de la zona malagueña (hasta el extremo de no constatarse ningún caso al oeste de la sierra de Bentomiz) $)^{43}$; en Guadix la situación es idéntica ${ }^{44}$. En cualquier caso, el número de moriscos malagueños en Antequera es muy alto tanto en términos absolutos como porcentuales y de ello es nuevamente indicativo el porcentaje que representan en las zonas finales de recepción de la población esclavizada fuera del Reino de Granada: en la ciudad de Sevilla, por ejemplo, los moriscos malagueños vendidos entre $1569-1571$ suponen un $18,5 \%$ frente al $26,7 \%$ de almerienses y el $54,7 \%$ de granadinos ${ }^{45}$.

${ }^{40}$ Datos calculados a partir de la información proporcionada en Vincent, "Economía y sociedad en el Reino de Granada", vol. IV, p. 184.

${ }^{41}$ Cabrillana, Almería morisca, pp. 272-273.

${ }^{42}$ Fernández Chaves y Pérez García, En los márgenes, pp. 97-98.

${ }^{43}$ Martín Casares, La esclavitud, pp. 185-186.

${ }^{44}$ Garrido García, "Guadix y su tierra”, pp. 85-86.

${ }^{45}$ Fernández Chaves y Pérez García, En los márgenes, pp. 96-97. Para el caso de Córdoba, que Aranda Doncel estudia en base a censos de 1573-1574, los moriscos malagueños suponían más del 14\% de los libres y en torno al 5,6\% de los esclavos (Aranda Doncel, Los moriscos en tierras de Córdoba, pp. 101-102). 
TABLA 6

Provincias (actuales) de origen de los moriscos presentes
en Antequera en 1573

\begin{tabular}{|l|r|c|}
\hline \multicolumn{1}{|c|}{ Provincia } & Número & Porcentaje \\
\hline Almería & 198 & 23,49 \\
\hline Granada & 298 & 35,35 \\
\hline Málaga & 217 & 25,74 \\
\hline Nacidos después de la guerra (en el destierro) & 16 & 1,89 \\
\hline Origen desconocido & 114 & 13,52 \\
\hline TOTAL & 843 & 100 \\
\hline
\end{tabular}

Los moriscos malagueños presentes en Antequera en 1573 proceden fundamentalmente de la Sierra de Bentomiz (105 casos) y de la Serranía de Ronda (49 individuos), constatándose también un número alto de los naturales de la tierra de Marbella (35, de ellos 14 de Benahavís y 12 de Istán) y de la de Málaga (20, de los cuales 12 eran de Monda).

El predominio numérico de los naturales de la Sierra de Bentomiz es fácil de comprender. Con una población morisca antes de la guerra que debía oscilar entre los 1.000 y los 1.600 vecinos $^{46}$, quizás algo más ${ }^{47}$, en la toma del fuerte de Frigiliana el 11 de junio de 1569, donde se habían agrupado los moriscos de toda la tierra de Bentomiz en las semanas anteriores, se cautivaron, según Mármol, 3.000 almas (casi

${ }^{46}$ Vincent, "Economía y sociedad en el Reino de Granada", vol. IV, p. 184, y Vincent, "Los moriscos granadinos: ¿una frontera interior?", pp. 173-174.

${ }^{47}$ Según Mármol Carvajal, Rebelión y castigo, pp. 180-181, en el fuerte de Frigiliana en junio 1569 habrían luchado 4.000 moriscos, de los cuales la mitad murieron en el asalto y la otra mitad huyó a las Alpujarras, aparte de un número indeterminado de moriscas que habrían preferido matarse o conseguido huir con sus hijos, así como otras 3.000 "almas" hechas cautivas. En total, más de 7.000 personas, correspondientes a la población morisca de la Sierra de Bentomiz agrupada en el fuerte desde las semanas anteriores (Mármol Carvajal, Rebelión y castigo, pp. 169-176). Las cifras de Hurtado de Mendoza son menores: 1.800 muertos (en el fuerte y después "en el alcance"), 500 heridos, casi 2.000 cautivos, aparte de los "mozos", que habrían conseguido huir en su mayoría (Hurtado de Mendoza, Guerra de Granada, p. 246, si bien es cierto que este texto da la impresión de querer reducir el "mérito" de esta victoria). Más información sobre la población de la Sierra de Bentomiz puede encontrarse en Pereiro Barbero, "Notas sobre población y urbanismo de la Axarquía. La incidencia de la guerra de Granada (1568)", pp. 79-93. 
2.000 según Hurtado de Mendoza), en su mayoría mujeres pues se refiere a ellas de modo repetido como "las esclavas". El reparto de este botín humano se habría realizado entre los soldados participantes en el asalto: los del corregimiento de Málaga y Vélez-Málaga de una parte (dirigidos por su corregidor Arévalo de Zuazo) y los de los tercios de Italia de otra ${ }^{48}$. Los cautivos fueron conducidos a la ciudad de Málaga, donde una comisión se hizo cargo de su reparto, que aún así, tardó varios meses hasta completarse ${ }^{49}$, hasta septiembre ${ }^{50}$. Entre los moriscos que documentamos en Antequera de los procedentes de la Sierra de Bentomiz, hallamos quince casos en los que se especifica que habían sido cautivados en el fuerte de Frigiliana, de otra se dice que "la cautivaron en un castillo de la sierra de Bentomiz", y a otra "en el fuerte de Torrox". De muchos más simplemente se apunta que los capturaron en la sierra de Bentomiz y en una quincena de casos que habían sido capturados en o junto a diversas poblaciones (Algarrobo, Salares, Sedella, Cómpeta, Periana, Bentomiz, ...) poniendo de relieve que los moriscos que no se refugiaron en el fuerte de Frigiliana y permanecieron en sus casas fueron igualmente esclavizados, y que otros muchos fueron cautivados mientras huían o buscaban refugio por los caminos, como a Diego, un morisco de sesenta años en 1573 natural del lugar de Rubite, "junto a Vélez", a quien "cautivaron en el camino de Vélez". Tuvo que ser desde Málaga, por lo tanto, y vía compra fundamentalmente, desde donde estos moriscos de la sierra de Bentomiz fueron desviados hacia Antequera. Hubo también algunos

${ }^{48}$ Sobre la participación de los tercios en el asalto de Frigiliana, aparte de la información proporcionada por Mármol, véase el excelente trabajo de Sánchez Ramos, "Los tercios de Italia y la guerra de los moriscos", pp. 77-112. También Navas Acosta, "La batalla de Frigiliana o la rebelión de Bentomiz", pp. 17-26.

${ }^{49}$ Mármol Carvajal, Rebelión y castigo, p. 181. Hurtado de Mendoza también afirma que la presa humana se repartió y vendió en Málaga, "entre todos [los soldados], a cada uno según le tocaba, repartiéndoles también el quinto del Rey" (Guerra de Granada, p. 247).

${ }^{50}$ Benítez Sánchez-Blanco, "Guerra y sociedad: Málaga y los niños moriscos cautivos. 1569", especialmente pp. 34 y 39. También sobre los niños moriscos en Málaga procedentes de la sierra de Bentomiz, véase Rabasco Valdés, "Dos aspectos de la esclavitud morisca. Málaga, 1569”, pp. 293-302. Esta cronología cuadra con el hecho de que no sea hasta octubre de 1569 cuando empezamos a documentar en Sevilla ventas de esclavos moriscos de los que se afirma explícitamente que son naturales de la Sierra de Bentomiz y capturados en Frigiliana, como Diego de 12 años (Archivo Histórico Provincial de Sevilla (en adelante AHPSe), Protocolos Notariales (en adelante PN), leg. 16036, f. 416r-v), Isabel de 25 (AHPSe, PN, leg. 17611), o Catalina de 28 (AHPSe, PN, leg. 4061, f. 833r-834r). 
casos de niños/as moriscos/as dados a encomienda y depósito. De hecho, conocemos el caso de un regidor de Antequera a quien se dio en la misma Málaga en depósito un niño de la sierra de Bentomiz ${ }^{51}$. El Registro de Antequera de 1573 también nos informa de otros seis casos en que niños o adolescentes moriscos de esta sierra habían sido puestos por el corregidor de la ciudad en administración o depósito de vecinos cristianos viejos $^{52}$. Otro niño de siete años estaba en administración del escribano público Gaspar de Torres por orden de Arévalo de Zuazo ${ }^{53}$, que había sido corregidor de Málaga y miembro de la comisión que sustanció la presa de Frigiliana.

Es posible que otra parte de los moriscos de la sierra de Bentomiz que hallamos en Antequera hubieran sido capturados posteriormente, en 1570. En efecto, en la campaña de don Antonio de Luna durante la primera quincena de marzo de 1570 con el objeto de deportar a los moriscos de la Axarquía ${ }^{44}$ y "destruyr los moros de Ventomiz"55, las tropas antequeranas colocadas bajo su mando recorrieron dicha sierra, aunque con escaso fruto, según Mármol, por quedar ya allí poco con que lucrarse y desertar de modo masivo ${ }^{56}$. En los primeros días de abril de 1570 don Antonio de Luna habría vuelto a salir de Antequera hacia la Sierra de Bentomiz ${ }^{57}$, tras reorganizar en los días precedentes un nuevo contingente en la ciudad ${ }^{58}$. Según Mármol y Hurtado de Mendoza, don Antonio de Luna habría partido de Antequera hacia la sierra de Bentomiz, desde donde, después de dejar dos guarniciones en sendos fuertes y mantener diversas escaramuzas con los rebeldes, habría vuelto con "la gente” a Antequera "con poca presa y pérdida igual"59. En ambas expediciones participaron tropas antequeranas, y

${ }^{51}$ Benítez Sánchez-Blanco, "Guerra y sociedad", p. 48.

${ }^{52}$ Registro, ff. 72, 73r-74r, 76r, 78v, 89r.

${ }^{53}$ Registro, f. $78 \mathrm{v}$.

${ }^{54}$ Fernández Chaves y Pérez García, En los márgenes, pp. 147-152.

${ }^{55}$ Como rezaba la cédula del duque de Sesa que este envía por orden de don Juan de Austria a la ciudad de Antequera, en cuyo cabildo se leyó el 11-II-1570, para que en ésta se levantasen tropas de infantería y caballería y se proveyese la intendencia necesaria (AHMA, AC, libro 1600, f. 121r).

${ }^{56}$ Mármol Carvajal, Rebelión y castigo, pp. 224-225.

${ }^{57}$ Hurtado de Mendoza, Guerra de Granada, p. 363 y nota 576.

${ }^{58}$ AHMA, FN, leg. 899. Entre los días 28 y 31 de marzo, al menos, se estaba formando la milicia correspondiente en Antequera.

${ }^{59}$ Mármol Carvajal, Rebelión y castigo, p. 239; y Hurtado de Mendoza, Guerra de Granada, pp. 363-364, que parece deudor de Mármol. 
en las dos se hicieron cautivos moriscos, si bien en número reducido.

Desde el comienzo de la rebelión en las Alpujarras, la estrategia del mando cristiano había pasado por impedir la extensión del conflicto hacia el área malagueña. Ese había sido el sentido último de las operaciones realizadas en la Sierra de Bentomiz (en mayo-junio de 1569 y marzo de 1570) y en la Axarquía (marzo de 1570), comarcas estratégicas en tanto que suponían el enlace natural con las Alpujarras. Por ello, en cuanto se tuvo noticia de la rebelión de Istán el 31 de diciembre de 1568 con ayuda de una partida de monfíes enviados por Farax Aben Farax, se actuó con extrema rapidez para asegurar todo el territorio malagueño, estableciendo guarniciones en Tolox, Monda y Casarabonela. Desde este momento inicial, en que se captura a las mujeres, niños y viejos de Istán (no en vano hallamos a una docena de moriscos de este lugar en Antequera en 1573), los hombres moriscos, "juntándose con otros que venían huyendo de tierra de Ronda y de la hoya de Málaga, quedaron hechos montaraces por aquellas sierras", e iniciaron una guerra de guerrillas que caracteriza una situación prácticamente inalterada hasta marzo de 1570, cuando comienza el proceso deportador, posible gracias a haber conseguido mantener el país aislado de los rebeldes alpujarreños ${ }^{60}$. El clima de inseguridad que vive la zona se caracteriza tanto por la acción de las partidas rebeldes, como por el comportamiento descontrolado de grupos de soldados desmandados o vecinos cristianos viejos que secuestran siempre que pueden a aquellos moriscos que caen en sus manos, incluidos los de las poblaciones de paces, bien de la tierra de Málaga ${ }^{61}$, bien de la de Marbella ${ }^{62} \mathrm{o}$ Ronda. A tenor de la información que vamos conociendo acerca de la situación de la zona malagueña durante 1569 , parece cada vez más claro que la suerte de las débiles y minoritarias poblaciones moriscas estaba echada, independientemente de su carácter rebelde o

${ }^{60}$ Para la rebelión de Istán y el comienzo de la guerra en área malagueña, Mármol Carvajal, Rebelión y castigo, pp. 121-123. También Bravo Caro, "Medidas adoptadas por el cabildo malagueño ante la sublevación morisca (1568-1570)", pp. 15-20.

${ }^{61}$ Un ejemplo que afecta a moriscos de paces de la zona de El Burgo, Yunquera, Tolox y Casarabonela, secuestrados por sus propios vecinos cristianos viejos, y luego intentados comercializar por otros de Antequera, en marzo de 1570, en Fernández Chaves y Pérez García, En los márgenes, pp. 122-125.

${ }^{62}$ Cabrillana, Marbella en el Siglo de Oro, pp. 221-225, donde se recogen ejemplos de moriscos de Daidín esclavizados ilegalmente, así como de otros que daban apoyo a los monfíes. 
no. Como ocurrió en el resto del Reino de Granada, la presión de los soldados cristianos viejos en busca de lucro fue demasiado fuerte como para que aquellos moriscos pudiesen seguir viviendo en paz.

Sin embargo, no fue hasta la última campaña de don Antonio de Luna en abril de 1570 cuando se acabó de extender la guerra al conjunto de la actual provincia de Málaga. El 20 de abril de 1570 salió de Antequera con 2.000 infantes y 60 de caballería, yendo a Ronda, donde prácticamente dobló sus efectivos. El objetivo de la campaña era deportar a los moriscos de la Serranía de Ronda, una zona no rebelada hasta el momento salvo "algunos levantados en aquellas sierras" que menciona Mármol y que responden a la conflictividad comentada. La campaña, como es sabido, se salda con un rotundo fracaso, pues, bien por la mala dirección de las operaciones, bien por el comportamiento indisciplinado de unas milicias improvisadas ávidas de botín, lo cierto es que la Serranía se levanta en armas contra lo que se considera una violación de los pactos firmados con la Corona. Como narra Mármol, desde el comienzo de la operación, los moriscos perciben el avance de los soldados y éstos "como gente bisoña y mal disciplinada, comenzaron a robar y cargarse de ropa y a recoger esclavos y ganados, hiriendo y matando sin diferencia a quien en alguna manera daba estorbo a su codicia". La reacción de los moriscos provoca diversas escaramuzas en las que las tropas de don Antonio de Luna son desorganizadas y, ocasionalmente, masacradas: "Vista la desorden y el poco efeto que se había hecho, retiró don Antonio de Luna las banderas con obra de mil y quinientos soldados, bien cargados de moriscas y de muchachos y de ropa y ganados, que vendían después en Ronda, como si fuera presa ganada de enemigos". No conocemos la actividad de aquel improvisado mercado esclavista en Ronda, pero lo cierto es que tras "liquidar" la mercancía, don Antonio de Luna deshizo los restos de su ejército, "dando licencia a la gente de Antequera, y enviando los moriscos que había podido recoger la tierra adentro" ${ }^{63}$. Sin duda, el regreso de los soldados a Antequera

\footnotetext{
${ }^{63}$ El relato anterior en Mármol Carvajal, Rebelión y castigo, pp. 248-249. Estas últimas palabras de Mármol nos informan claramente de que, a pesar del fracaso global de la expedición a la Serranía de Ronda, sí se realizó la "saca" de una parte de la población morisca de la Serranía fuera del Reino de Granada. No en vano, el 29 de julio de 1570, al informar desde Casares al Rey del asunto de las negociaciones de capitulación de los moriscos rebeldes de la Serranía de Ronda, el duque de Arcos escribía: "Estos que se an
} 
hacia finales del mes de abril de 1570 supuso la llegada a la ciudad de un buen número de moriscos cautivos del área rondeña, presentes (al menos en parte) todavía en ella en 1573, donde documentamos medio centenar de "piezas" de al menos 17 poblaciones de la Serranía.

Otra parte de estos moriscos fue capturada en las operaciones sostenidas posteriormente en aquella sierra, ya bajo la dirección del duque de Arcos (encargado por el Rey de hacerse cargo de aquel frente en sustitución de don Antonio de Luna), especialmente en la campaña del mes de septiembre en que este expugnó el fuerte de Arboto ${ }^{64}$ (cerca de Istán, donde se habían fortificado buena parte de los moriscos de la Serranía de Ronda, y fueron capturados 500 mujeres y niños ${ }^{65}$, y en los días siguientes en las maniobras en que se apresó, redujo o exterminó a muchos de los que desde Arboto se habían dispersado ( "unos fueron a Río Verde, otros la vuelta de Istán, otros a Monda, y otros a Sierra Blanquilla" ${ }^{66}$ ). Es precisamente en este contexto final de la guerra cuando se produce el vaciado del resto de la provincia de Málaga, que afecta especialmente a la zona de Monda, Ojén y la Hoya de Málaga, que recorren las tropas de Arévalo de Zuazo en coordinación con las del duque de Arcos durante los últimos días de septiembre y primeros de octubre ${ }^{67}$.

Durante los meses de septiembre y octubre de 1570 se vive en la parte central y occidental de la provincia una auténtica cacería en la que las tropas persiguen a las partidas de rebeldes y fijan presidios en

de reduzir tienen munchos dellos sus mugeres y hijos en Éçija y Carmona y Marchena y Arcos y en algunos otros lugares divididos...", considerando la oferta de una "reunificación" familiar como un aliciente para estimular su rendición (Benítez SánchezBlanco, Moriscos y cristianos en el Condado de Casares, p. 306). Sobre la llegada de moriscos de la Serranía de Ronda a Carmona, véase Maier Allende, "Los moriscos de Carmona", pp. 85-118, y para Écija, Aranda Doncel y Martín Ojeda, "Evolución demográfica y estructura de la población morisca en la ciudad de Écija", pp. 227-251.

${ }^{64}$ El 26-VII-1573, un vecino de Antequera, Diego Ruiz de Olivares, registraba un niño morisco del que decía ignorar su procedencia, el nombre de sus padres y su edad y que se llamaba Diego (seguramente por haberle dado él mismo su propio nombre), " $y$ el dicho Diego Ruiz dixo que lo ovo en Arbote yendo por general el duque de Arcos" (Registro, f. 96r). Si bien parece que las milicias de Antequera no participaron en la toma de Arboto (Benítez Sánchez-Blanco, Moriscos y cristianos, pp. 307-335, en concreto p. 322, en carta de 5-IX-1570 se explicita que faltaba la tropa de Antequera, que no aparece después en el relato del asalto).

${ }^{65}$ Mármol Carvajal, Rebelión y castigo, pp. 261 y 263-264.

${ }^{66}$ Mármol Carvajal, Rebelión y castigo, p. 264.

${ }^{67}$ Mármol Carvajal, Rebelión y castigo, pp. 264-265; Benítez Sánchez-Blanco, Moriscos y cristianos, pp. 333-334 y 336. 
lugares estratégicos, al tiempo que grupos de soldados descontrolados atacan tanto los lugares de moriscos que permanecían en paz como las propias columnas de deportados en un intento final de capturar esclavos. La correspondencia del duque de Arcos con el Rey es sumamente ilustrativa en este sentido. Algunos ejemplos nos dan la tónica de los hechos:

- a fines de agosto el duque se refiere a los "desórdenes" habidos en Marbella en relación a los moriscos de Benahavís y Daidín que se habían reducido y entregado sus armas, y habían ido a aquella ciudad "por sus mugeres" 68 ;

- el 2 de septiembre los moriscos que habían ido a reducirse a la ciudad de Ronda habían sido atacados brutalmente por "mucha gente desta çiudad ... buscándolos y matando los que topavan", ante lo cual, y con el objeto de salvar a los que quedaban, el duque los había mandado escoltados a Montejaque; por el camino, algunos vecinos de Ronda junto con soldados de las compañías seleccionadas para protegerlos, los habían asaltado y masacrado. Los que se salvaron fueron depositados en Montejaque ${ }^{69}$;

- el 9 de octubre daba cuenta del ataque de "çierta gente desmandada de Ximena y Casares y Gauçín vinieron ayer a dar sobre los reduzidos de un lugar çerca de aquí que se dize Cartágima" $"$.

La situación de caos general vivida en la zona por la acción descontrolada de soldados y vecinos cristianos viejos se pone de manifiesto en una carta del Duque de Arcos al Rey de 21 de octubre:

\footnotetext{
"Tratando con el alcalde Barahona díxele quanto convenía que se castigasen algunos vezinos desta comarca que andan en quadrillas haziendo daño a los reduzidos, me dixo que si no era con espressa orden de V. M. no podía tratar del castigo dello porque las comiciones que hasta aora tiene no se alcanzan más que a los de Marbella y lo de aquí [Ronda], y que sería menester que V. M. se la mandase
}

${ }^{68}$ Benítez Sánchez-Blanco, Moriscos y cristianos, p. 320. Carta de 31-VIII-1570. Del atropello sufrido previamente por los moriscos de la tierra de Marbella, de las ventas de esclavas moriscas de Benahavís a partir de estas fechas, y de las encomiendas de niños moriscos de esta población, da cuenta Cabrillana, Marbella en el Siglo de Oro, pp. 227-231.

${ }^{69}$ Benítez Sánchez-Blanco, Moriscos y cristianos, pp. 321-322. Carta de 5-IX-1570.

${ }^{70}$ Benítez Sánchez-Blanco, Moriscos y cristianos, p. 342. 
dar, y porque en Montexaque y Algatoçín an hecho grandes robos estos días y puesto fuego a una iglesia de uno destos lugares, y no enbargante la diligencia que he hecho poner en avisar por la comarca que prendan los que llevaren esclavos a vender sin el recaudo que deven $l l e v a r^{71}$, no se ha podido prender ningún culpado" 72 .

El punto final de esta situación se habría querido buscar en la deportación general, realizada en la zona de Ronda el 31 de octubre de 1570 desde los puntos de concentración (Jubrique y Cartájima, entre otros) y bajo escolta militar para impedir los asaltos de cristianos viejos $^{73}$. No obstante, la actividad de las partidas de rebeldes y monfíes se habría alargado durante años en el área malagueña ${ }^{74}$.

Resulta evidente que la mayor parte de los numerosos moriscos de la Serranía de Ronda y las tierras de Marbella y Málaga presentes en Antequera en 1573 habían sido llevados allí como resultado de esta situación caótica y de abuso vivida en estos territorios durante el final del verano y el otoño de 1570. Es llamativo que documentemos en Antequera nada más y nada menos que quince moriscos/as (todos ellos esclavizados) de Montejaque, una población que no llegó a sublevarse $^{75}$, y que quizás por ello sirvió de "depósito" de otros moriscos reducidos, como vimos. Sin embargo, fueron cautivados en el transcurso de su deportación, como algunos pusieron de manifiesto en 1573 ante el corregidor de Antequera: así, una muchacha llamada María Martín dijo que "la cautivaron en el camino de Álora"76, o el viejo Hernán Martín explicó "que viniendo del fuerte antes que se tomara por los cristianos se venía él y una hija suya que está en casa de Juan de Cisneros y otros moriscos y mugeres que yvan a la villa de Teva de paz, le salieron junto a Álora yendo por el camino los cristianos y lo cautivaron, pero que no yvan de guerra sino de paz" $" 77$.

${ }^{71}$ Sobre los recaudos y permisos que se hicieron obligatorios en la última fase de la guerra con el objeto de controlar el tráfico ilegal de esclavos moriscos, Fernández Chaves y Pérez García, En los márgenes, pp. 95, 125-126.

${ }^{72}$ Benítez Sánchez-Blanco, Moriscos y cristianos, pp. 345-346. Ronda, 21-X-1570.

${ }^{73}$ Benítez Sánchez-Blanco, Moriscos y cristianos, p. 196.

${ }^{74}$ Entre 1572 y 1574 todavía actúan en la serranía una decena de bandas, y en 1577 se seguía persiguiendo al morisco Juan Tangue, alias el Tanjarillo (Benítez Sánchez-Blanco, Moriscos y cristianos, pp. 177-178).

${ }^{75}$ Domínguez Ortiz y Vincent, Historia de los moriscos, p. 42.

${ }^{76}$ Registro, f. 47.

${ }^{77}$ Registro, f. 66. 
Idéntico es el caso de los siete moriscos de Benaoján, y otros tantos de Benarrabá, Alpandeire, Faraján y Algatocín, todos ellos esclavos y procedentes asimismo de lugares de la Serranía de Ronda que tampoco se rebelaron ${ }^{78}$. En 1573, muchos de aquellos moriscos, la mayoría mujeres, alegaron ante el corregidor de Antequera su ilegal esclavización ${ }^{79}$. La versión de María Hernández, natural de Benadalid, se repite grosso modo una y otra vez: "la cautivaron junto a Istán viniendo de pazes todas las mugeres por el camino"80.

Otros grupos numerosos de moriscos en Antequera proceden de: Benahavís (14), azotada también por el comportamiento abusivo y descontrolado de los vecinos cristianos viejos, como vimos; Ojén (8), y Monda (12), poblaciones muy castigadas por las operaciones del otoño de 1570, y en el caso de la última, junto a Tolox (de donde procede otro morisco de los que hallamos en Antequera) y Guaro (con otros tres individuos), objeto de una deportación previa realizada el 23 y 24 de abril que supuso la saca de más de un millar de moriscos ${ }^{81}$, aparte de una operación militar dirigida por el corregidor Arévalo de Zuazo sobre Tolox (que era complementaria del intento de saca de don Antonio de Luna en la Serranía de Ronda) y que acabó de modo trágico para los soldados del Rey ${ }^{82}$.

${ }^{78}$ Domínguez Ortiz y Vincent, Historia de los moriscos, p. 42. Una de las de Benaoján, Catalina, contó después que la cautivaron "junto a Monda" (Registro, f. 48).

${ }^{79}$ Fernández Chaves y Pérez García, En los márgenes, pp. 129-130.

${ }^{80}$ Registro, f. $44 \mathrm{v}$.

${ }^{81}$ IVJ, envío 1, ff. 65 y 71, donde se describe minuciosamente la saca de los moriscos de Tolox en 23/24-IV-1570, en la que reina el orden hasta que se tiene "aviso que cantidad de moros venían a la dicha villa", y durante la apresurada retirada se producen algunos asesinatos y secuestros de moriscos. De Tolox, Monda, Guaro y Casarabonela, los cuatro lugares afectados por esta deportación, se sacaron según Arévalo de Zuazo "mill personas de catorze años arriba hasta setenta, sin las mugeres e criaturas y viejos"; en Tolox, llamando por el padrón de confesiones, faltaron 130 personas, "los más dellos ausentes desde el principio del levantamiento"; en Monda faltaron 125, en Guaro entre 50 y 60, y en Casarabonela tres o cuatro. También sobre este asunto Domínguez Ortiz y Vincent, Historia de los moriscos, p. 55, que sitúan erróneamente esta deportación en mayo. El dos de mayo un grupo de moriscos de Tolox llegaba ya a Carmona (Fernández Chaves y Pérez García, En los márgenes, p. 189); otros de los deportados en esta ocasión fueron trasladados hasta Écija (IVJ, envío 1, f. 71). Véase la nota siguiente.

${ }^{82}$ Mármol Carvajal, Rebelión y castigo, pp. 249-250. Esta maniobra sobre Tolox hubo de realizarse en el mes de abril, habida cuenta de su coordinación con la entrada de don Antonio de Luna en la Serranía de Ronda. 


\section{La expulsión de esclavos moriscos de Antequera en 1574. Las permanencias}

La expulsión de los esclavos moriscos de Antequera se ordenó antes incluso de la elaboración del registro del verano de 1573. Aunque no conocemos el momento exacto, lo cierto es que es muy probable que ésta se hubiera planteado ya en 1572 o comienzos de 1573, pues en una cédula real de 2 de marzo de 1573, don Pedro de Deza se refería a la petición presentada por la ciudad de Antequera para que no se aplicase en ella la orden de que "los esclavos captivos naturales de ese Reyno [de Granada] que hay en la dicha ciudad se saquen della y se vendan de esta parte de Guadiana", alegando la necesidad que había de ellos para las labores del campo ${ }^{83}$. En esa misma cédula se ordenaba a la ciudad de Antequera la elaboración de un registro de los esclavos moriscos, que sería anterior, por tanto y como hemos visto, al elaborado a raíz del pregón en Antequera en 28-VI-1573 de la Pragmática de 6$\mathrm{X}-1572$. No obstante, vuelta a valorar la petición de la ciudad por el Rey, este ordenó se ejecutase la saca de todos los esclavos moriscos varones mayores de 14 años, como se hizo saber al corregidor por don Pedro de Deza el 27 de noviembre de 1573. En esta orden, el presidente de la Chancillería justificaba la medida regia "por los daños e ynconvenientes que pudieran subceder de estar tan cerca de las sierras deste reino" ${ }^{84}$. Lejos de responder a excusas, delataba las notables dificultades que desde el final de la guerra se habían experimentado en los diferentes intentos de reducir las partidas de monfíes que azotaban las serranías malagueñas.

La orden definitiva de don Pedro de Deza, Presidente de la Chancillería de Granada y Capitán General del Reino de Granada, para sacar a los esclavos moriscos, llegó a Antequera el día 6 de enero de 1574. Ese día, el corregidor de la ciudad don Blasco de Villarreal recibía el mandamiento para proceder a la saca en el plazo de diez días de todos los esclavos moriscos varones de más de 14 años, los cuales deberían ser llevados a "la otra parte del río de Guadiana". Para llevarla a efecto el corregidor recurrió al registro de esclavos realizado

${ }^{83}$ AGS, CC, libro de cédulas 261, f. 26r-v. Véase Apéndice documental, documento 1.

${ }^{84} \mathrm{El}$ documento se conserva en AHMA, FM, leg. 3298. Véase Apéndice documental, documento 2.

${ }^{85}$ AHMA, FM, leg. 3298. Antequera, 6-I-1574. 
el verano anterior, y dispuso la elaboración de seis copias con las cuales los escribanos notificarían a los dueños lo dispuesto por el Rey ${ }^{85}$. Durante el mes de enero se suceden estas notificaciones a los amos para que "lo envie o lleve [a su esclavo] de aquella parte del Guadiana”. En los mismos días y en los primeros de febrero, algunos amos acuden al corregidor para excusarse del cumplimiento de la notificación en base a que ya no poseen el esclavo por el que habían sido requeridos por haberse muerto este o haberlo vendido fuera de la ciudad $^{86}$, o simplemente intentando eludir la orden alegando que se hallaba enfermo o lisiado. Ante el hecho de que había "personas que se han ausentado" para esconder a sus esclavos y eludir la saca, el corregidor proveyó que un escribano público acompañado de un alguacil recorriese el término de la ciudad y sus numerosos cortijos con el objeto de que notificasen la orden a cualquier persona que fuese pertinente. El día 18 de enero el corregidor dispuso que los vecinos que tuvieran a su cargo niños moriscos los llevasen a su presencia con el objeto de dictaminar sobre su edad y decidir si les afectaba o no la orden de expulsión. En los días siguientes, distintos vecinos presentaron al corregidor aquellos niños moriscos varones que tenían en sus casas, y unos sesenta fueron declarados no comprendidos en el bando de expulsión. En algún caso la solicitud de conservar al esclavo no fue aceptada por don Blasco de Villarroel, si bien también se dieron situaciones en que se permitió un cierto retraso en la saca: por ejemplo, cuando el regidor Bartolomé Chacón muestra al corregidor a su esclavo morisco Francisco, este lo declara comprendido por el bando, si bien concede a Chacón un plazo de seis meses para que "lo lleve e envie de la otra parte del río de Guadiana" 87.

La expulsión de los esclavos moriscos varones mayores de catorce años era un hecho y se llevó a cabo por lo tanto en las primeras semanas

${ }^{86}$ Como don Juan de Mancha Velasco, vecino de Antequera, que explicó que había vendido al esclavo morisco Garci González a don Pedro Ponce de León, vecino de Sevilla, el 1 de febrero de 1573, presentando traslado de la escritura de venta. Rodrigo de Narváez, regidor de Antequera, vendió otro esclavo morisco en Benamejí a un vecino de la villa el 10 de enero de 1574, y otros lo hicieron a otras personas (de Paterna, jurisdicción de Sevilla; o de Ciudad Rodrigo). Es posible que estos últimos casos de apresuradas ventas respondan al intento de los amos de deshacerse cuanto antes de los esclavos y evitarse el traslado de los mismos.

${ }^{87}$ Toda la información anterior está recogida en un grueso expediente conservado en AHMA, FM, leg. 3298. 
de 1574. ¿A cuántos individuos afectó realmente? Según la ciudad de Antequera alegaba en su petición para impedir la saca, no pasaban de 250 individuos sobre una población de más de 6.000 vecinos cristianos viejos $^{88}$. Aunque se podría pensar en una cifra intencionadamente subestimada por la ciudad dado su objetivo de minimizar su importancia, lo cierto es que según el registro de moriscos de Antequera del verano de 1573, sólo habría ya unos 169 esclavos moriscos varones mayores de 14 años en ese momento, lo que implica que durante los meses anteriores (en realidad desde el final de la guerra) habría existido un continuo flujo de salida de esclavos moriscos de Antequera, bien por venta hacia el norte, bien por fuga ${ }^{89}$.

Por lo tanto, parece claro que tras la saca de estos esclavos a comienzos de 1574, quedaron en la ciudad todavía unos 700 moriscos, mujeres y niños casi todos, en una situación de esclavitud legal que les afectaba en la mayoría de los casos, y en una realidad de sometimiento casi absoluto, como ponen de manifiesto los abundantes procesos que en los años siguientes protagonizan un buen número de moriscos reclamando su libertad ${ }^{90}$, o la nueva orden del corregidor en 1580 a las personas que registraron niños y niñas moriscos en 1573, o los tenían ahora en administración, de que los llevasen a su presencia, ya que "todos los moriscos e moriscas de menor hedad que conforme a ella no podian ser cautivos e munchas personas de las que registraron los dichos moriscos los tienen vendidos e dispuesto dellos, e otros los tienen herrados, e no les han enseñado ni instruido en las cosas de la santa fe católica, e conviene poner remedio..." ${ }^{\prime 1}$.

${ }^{88}$ Apéndice documental, documento 1.

${ }^{89}$ En carta de 24 de octubre de 1572, el corregidor de Antequera don Fadrique Manrique se quejaba de que los moriscos de Antequera eran "tan moros como los de Berbería", sin oír nunca misa ni recibir los sacramentos, y considerando conveniente que los días festivos se les reuniera en las parroquias y se les pasara revista, para así controlar que no huyeran a las sierras de Bentomiz, Tejeda o Comares, como algunos esclavos ya habían hecho (Cabrillana, "El problema morisco en la correspondencia del Cardenal Espinosa", p. 142).

${ }^{90}$ Véanse: AHMA, FM, legs. 3292 y 3298; y Archivo Histórico Nacional, Concejos y ciudades, leg. 25.

${ }^{91}$ AHMA, FM, leg. 3292. Antequera, 7-VIII-1580. 


\section{Epílogo}

Esta situación, heredera directa de la guerra y las políticas regias de control de la población morisca, se alargaría de un modo u otro hasta 1584 , cuando se procede a una nueva deportación casi general de los moriscos que habían quedado en el Reino de Granada y en las zonas fronterizas al mismo, afectando de nuevo a Antequera, de donde se sacaron en esta ocasión más de 400 moriscos $^{92}$. No obstante, es necesario un estudio preciso del periodo 1574/75-1584 con sus correspondientes procesos deportatorios, mal conocidos todavía, pero que exceden ya el objeto y posibilidades de estas páginas. Sólo recordar que la saca de los esclavos moriscos de Antequera a comienzos de 1574 forma parte de un proceso más amplio que afecta a toda la frontera del antiguo Reino de Granada entre 1574 y 1575 . En octubre de 1573 se había alistado a los moriscos que permanecían en el marquesado de Los Vélez y en mayo del año siguiente los varones mayores de 14 años fueron llevados a Toledo ${ }^{93}$. A fines de mayo de 1574, no obstante, don Pedro de Deza volvió a paralizar la saca de los esclavos moriscos varones mayores de 14 años presentes en la banda fronteriza, considerando los problemas y peligros que comportaba la operación, y que ya quedaban pocos monfíes; no obstante, en julio se había vuelto a poner en marcha, enviándose las instrucciones correspondientes a Alcalá la Real, Teba, Ardales, Cañete, Olvera, Archidona, Jimena de la Frontera, Zahara y Alcalá de los Gazules ${ }^{94}$. La aplicación, no obstante, no fue rápida. Hasta el 4 de noviembre de 1574 no se hace en Alcalá la Real y Castillo de Locubín el registro de los esclavos moriscos mayores de 14 años, sumándose 89 de éstos entre ambas poblaciones; en los días siguientes se les deportó hacia el interior ("treinta leguas fuera del Reino"), en medio de grandes protestas de los vecinos ${ }^{95}$. Esta fase de las deportaciones se debió alargar, al menos,

${ }^{92}$ La deportación de 1584 fue estudiada por Lapeyre en su Geografía de la España morisca. Para Antequera, Resa Moncayo, "Realidad morisca en Antequera (1560-1585)", pp. 423-433.

${ }^{93}$ AGS, CC, leg. 2175.

${ }^{94}$ AGS, CC, leg. 2175. Apéndice documental, documento 3.

${ }^{95}$ AGS, CC, leg. 2175. El corregidor de Alcalá la Real escribía a don Pedro de Deza, tras la saca, "que le querían apedrear los vecinos pareciéndoles que él de su autoridad los hazía sacar porque lo sintieron más que si les sacaran sus mismos hijos, tanto es el amor que tienen con ellos y el aborrecimiento con que hacen executar lo que se les manda". 
hasta mediados de 1575. Según un cronista de Aracena, en junio de 1575 "mandó el rey don Felipe nuestro señor: que todos los moriscos que fuesen naturales del reyno de Granada que estuviesen treinta leguas del dicho reyno y no alojados, los fuesen a alojar a otras partes hazia Castilla, con sus mugeres y hijos, y los captivos de diez años arriba dentro de tres días saliesen fuera del dicho reyno, y dello presentasen sus amos testimonios. Apregonose ansí públicamente. Vinieron a vender a esta tierra y villa de Aracena algunos, y algunos dexaron trabajando puestos por sus amos sin los vender" $"$.

Así pues, el estudio de la población morisca en Antequera en 15691574 nos ofrece una excelente radiografía de una época muy precisa en la historia de los moriscos granadinos caracterizada por un alto grado de inestabilidad y desestructuración familiar y comunitaria.

\section{Apéndice documental}

- Documento 1. AGS: CC, libro de cédulas 261, f. 26r-v. Madrid, 2-III-1573. "El Rey.

[al margen: "La çiudad de Antequera"]

Don Pedro de Deça, Presidente de la nuestra audiençia y chançilleria que reside en la çiudad de Granada, por parte de la çiudad de Antequera nos ha sido hecha relaçion que nos tenemos mandado que los esclavos cauptivos naturales de ese Reyno que ay en la dicha çiudad se saquen della y se vendan de esta parte de Guadiana, lo qual es en gran daño y perjuizio de la dicha çiudad y vezinos della porque los dichos esclavos no pasan de dosçientos y çinquenta haviendo en ella mas de seis mill vezinos christianos viejos y que demas de no haverse ydo ni ausentado en ningund tiempo, son muy utiles y de mucha ymportançia para la labor del campo, que es el prinçipal tracto de la dicha çiudad en la qual ay gran falta de otra gente para este efeto a causa de haver muerto en la guerra mucha parte de la que entendia en esto y haverse ydo a poblar a la Alpuxarra y Axarquia la que havia quedado y que no se halla quien sirva sino en muy excesivos preçios porque en tiempo de agosto lleva un hombre por medio dia que va a segar siete reales y de alli arriba, y con los dichos esclavos repartidos entre los vezinos como lo estan se remedian los labradores y si les faltasen se perderia mucha parte de la labor y quedarian perdidos los que la traen, demas del inconbiniente que resultaria

${ }^{96}$ Memorias y sucesos notables de Europa, especialmente de Aracena y de sus inmediaciones (Anales de 1558-1611), p. 88. 
a la probision que de alli se haze de trigo y çebada y otras cosas para nuestras armadas y fronteras, suplicandonos seamos servido de mandar que los dueños de los dichos esclavos no sehan apremiados a que los vendan pues siendo neçessario se obligaran a pagar qualquier daño que sus esclavos hizieren y a la guarda y custodia dellos, y porque queremos saber el numero de esclabos de los naturales de ese Reyno que ay en la dicha çiudad de Antequera y si todos o algunos dellos son utiles para la labor del campo, y si en la dicha çiudad ay tanta falta de gente para este uso como se contiene en su relacion, y si combiene y es neçessario por todas las causas que estan referidas que queden en la dicha çiudad todos los dichos esclavos o parte de ellos para el dicho efetto obligandose los dueños a la guarda y custodia dellos y a los daños que hizieren sin que desto se siga o pueda seguir algund yncombiniente o lo seria y por que causa, os encargamos que proveais que se haga registro de los esclavos naturales de ese Reyno que al presente ay en la dicha çiudad de Antequera y cuyos son y haviendolo tractado y comunicado con las personas que ay se juntan con vos a las cosas de ese Reyno, nos envieis relacion particular de todo lo susodicho juntamente con un treslado del dicho registro y de lo que alla paresçe se deve proveher y entretanto que vista (sic) embiamos a mandar lo que en ellos somos servido proveereis que no se saquen de la dicha çiudad los esclavos que en ella ay al presente que sean utiles para la labor del campo haziendo los dueños dellos obligaçion que los tendran en buena guarda y custodia y que si algun daño hizieren lo pagaran advertiendo de prevenir que con esta occasion no queden en ella los que no fueren para este proposito ni se metan otros de fuera, y que so color que son esclavos no queden en la dicha çiudad moriscos como los dias passados nos escrevistes que avia alli algunos desta calidad, que para que se pueda mejor advertir a ello se os enbian con esta las Peticiones y otros papeles que por parte de la dicha çiudad se presentaron ante nos. De Madrid, a dos de março de 1573 años. Yo el Rey. Refrendada de Juan Vazquez, sin señal".

- Documento 2. AHMA: FM, leg. 3298. Granada, 27-XI-1573.

"Don Pedro de Deza. Presidente en la audiencia real de Granada por orden de su magestad. Por quanto aviendose mandado que todos los esclavos varones mayores de catorze años de los naturales deste rreino que oviese en la ciudad de Antequera se sacasen della por los daños e ynconvenientes que pudieran subceder de estar tan cerca de las sierras deste rreino, por parte de la dicha ciudad se ocurrio a su magestad e se le suplico lo mandase sobreseir por la necesidad que los vecinos della tenian de los dichos esclavos para sus labores y su magestad mando que se le embiase relacion cerca dello e aviendosele enviado a mandado que sin embargo dello se cunpla y execute lo que estava ordenado e para que aquello aya cunplido efecto mande dar la presente por la qual ordeno e de parte de su magestad mando a don Blasco de Villarroel corregidor de la dicha ciudad de Antequera que luego que le fuere entregada haga requerir e notificar a todos los vezinos de la dicha 
ciudad que tubieren de los dichos esclavos que conforme a las obligaciones e fianzas que tiene hechas dentro de diez dias primeros siguientes los saquen e lleven a vender e dispongan dellos de aquella parte de Guadiana y dentro de veinte dias luego siguientes traigan testimonios a esta corte ante el secretario Hernando de Castro de como lo an hecho e cunplido assi apercibiendoles que pasado el dicho termino no lo aviendo cunplido se cobraran dellos y de sus bienes las penas contenidas en las dichas obligaciones e fianzas sin remision alguna, de mas de que yncurriran en pena de perdimiento de los dichos esclavos que asi fueren hallados y de treynta ducados repartidos los diez para el que los prendiere o denunciare que estan en el reyno, y los diez para el juez que lo sentenciare, y los diez restantes para gastos de justicia de la guerra, y lo mismo por los esclavos que se fueren e ausentaren y no dieren quenta dellos, todo lo qual se haga con todo el secreto e disimulacion que sea posible y de manera que no nazcan ni se sigan nuevos ynconvenientes, y de lo que se hiziere me embie rrelacion y testimonio de las notificaciones y cumplimiento para que se pueda dar quenta a su magestad...”. Dada en Granada a 27 de noviembre de 1573. Firma de Don Pedro de Deza, y de Basilio de Torres "por mandado de su Illma.".

- Documento 3. AGS: CC, leg. 2175. Granada, 12-VII-1574. El presidente de la Chancillería de Granada al Rey.

"En carta de 30 de mayo, respuesta de la de VM en que me mando se sacasen fuera de este reyno los esclavos moriscos que avia en los lugares convecinos a el, di quenta a VM de las deligencias que hasta entonces se avian hecho, y dixe como se avia suspendido por entonces la saca dellos, por parecer que haziendose esta mudanza seria posible alborotarse y yrse algunos a la sierra donde a la sazon avia frutas y otras cosas de bastimento con que podrian entretenerse muchos dias y ser occasion de mucho cuydado y costa para averse de prender, y que bendito dios estaba la tierra casi limpia de monfies seria bien diferir la saca de estos esclavos para tiempo mas comodo y de menos ynconviniente, y porque despues aca a sucedido en Alcala la Real cierta muerte de un cristiano que los esclavos de aquella ciudad hizieron, y el corregidor de Ronda me volvio a escribir que seria bien sacar los que estan en los lugares de aquel contorno, hize luego despachar ordenes a las Justicias de Alcala la Real, Teba, Ardales, Cañete, Olvera, Archidona, Ximena, Zahara, y Alcala de los Gazules para que cada uno en su lugar y distrito hiziese recoger todos los moriscos esclavos de quatorze años arriba y recogidos los entregasen a sus dueños dando fianzas bastantes de sacarlos dentro de 20 dias y disponer dellos 30 leguas de los dichos lugares y otras tantas de la costa, y dentro de otros 20 siguientes traygan aqui testimonio de como lo uvieren cumplido, todas estas ordenes sino es la de Alcala la Real y Archidona se embiaron al corregidor de Ronda para quel las encaminase de su mano a las justicias de aquellos lugares por ser del contorno de aquel corregimiento y anme respondido casi todos diziendo como recogieron luego los esclavos y los 
entregaron a sus dueños con las dichas fianzas y pidiendome con grandisima instancia alguna prorrogacion de tiempo para sacallos por tener ya el agosto en las manos y no poder en ninguna manera hazerlo sin ayuda de sus esclavos, y pareciendome muy justa su demanda y muy poco el peligro de la dilacion y tambien por gratificarles en algo la voluntad con que sirven a VM en las ocasiones que se ofrecen se les prorogaron otros 20 dias mas con que acabados aquellos luego se pusiese execucion lo que esta ordenado, de todo lo que adelante sucediere yre dando quenta a VM...". Don Pedro de Deza, en Granada a 12 de julio de 1574.

\section{Bibliografía}

Aranda Doncel, Juan, Los moriscos en tierras de Córdoba, Córdoba, Monte de Piedad y Caja de Ahorros de Córdoba, 1984.

Aranda Doncel, Juan y Martín Ojeda, Marina, "Evolución demográfica y estructura de la población morisca en la ciudad de Écija", Actas III Congreso de Historia “Écija en la Edad Media y Renacimiento", Sevilla, Universidad, 1993, pp. 227-251.

Asenjo Sedano, Carlos, Sociedad y esclavitud en el Reino de Granada s. XVI, Granada, Ilustre Colegio Notarial de Granada, 1997.

Asenjo Sedano, Carlos, "Trabajo, honra y esclavos en la Granada de los siglos XV/XVII", Revista del Centro de Estudios Históricos de Granada y su Reino, 6 (1992), pp. 223-254.

Benítez Sánchez-Blanco, Rafael, Moriscos y cristianos en el Condado de Casares, Córdoba, Diputación, 1982.

Benítez Sánchez-Blanco, Rafael, "Guerra y sociedad: Málaga y los niños moriscos cautivos. 1569”, Estudis, 3 (1974), pp. 31-54.

Bravo Caro, Juan Jesús, Felipe II y la repoblación del Reino de Granada. La taha de Comares, Granada, Universidad de Granada y Universidad de Málaga, 1995.

Bravo Caro, Juan Jesús, "Medidas adoptadas por el cabildo malagueño ante la sublevación morisca (1568-1570)", Jábega, 52 (1986), pp. 15-20.

Cabrillana, Nicolás, "El problema morisco en la correspondencia del Cardenal Espinosa", in Abdeljelil Temimi (ed.), Mélanges Louis Cardaillac, Zaghouan, Fondation Temimi, 1995, vol. I, pp. 133-143.

Cabrillana, Nicolás, Almería morisca, Granada, Universidad, 1989, $2^{a}$ ed.

Cabrillana, Nicolás, Marbella en el Siglo de Oro, Granada, Universidad, 1989.

Cuenca Gñecco, Victoria, Adra la Vieja. Siglo XVI, Adra-Almería, Diputación Provincial de Almería, 1985.

Domínguez Ortiz, Antonio y Vincent, Bernard, Historia de los moriscos. Vida y tragedia de una minoría, Madrid, Alianza, 1985. 
Fernández Chaves, Manuel F. y Pérez García, Rafael M., "Notas sobre la destrucción de las comunidades moriscas malagueñas y su reconstrucción en la campiña sevillana, 1569-1610”, Áreas, 30 (2011), pp. 121-139.

Fernández Chaves, Manuel F. y Pérez García, Rafael M., En los márgenes de la Ciudad de Dios. Moriscos en Sevilla, Valencia, Universidad, 2009.

Garrido García, Carlos Javier, "Guadix y su tierra durante el primer año de la rebelión de los moriscos (1569): guerra y esclavitud", Boletín del Centro Pedro Suárez, 24 (2011), pp. 73-108.

Garrido García, Carlos Javier, La esclavitud en el Reino de Granada en el último tercio del siglo XVI: el caso de Guadix y su tierra, tesis doctoral defendida en la Universidad de Granada en 2011.

Garrido García, Carlos Javier, "La esclavitud en el reino de Granada y la rebelión de los moriscos. El caso de la diócesis de Guadix: el papel del estamento eclesiástico", Miscelánea de Estudios Árabes y Hebraicos, 49 (2000), pp. 4588.

Hurtado de Mendoza, Diego, Guerra de Granada, edición, introducción y notas de Bernardo Blanco-González, Madrid, Castalia, 1970.

La expulsión de los moriscos del Reino de Granada (pragmáticas, provisiones y órdenes reales), edición facsímil con una introducción de Francisco Izquierdo, Madrid, Editorial Azur, 1983.

Lapeyre, Henri, Geografía de la España morisca, Valencia, Diputación, 1986.

Maier Allende, Jorge, "Los moriscos de Carmona", III Congreso de Historia de Carmona. Carmona en la Edad Moderna, Carmona, Universidad de Sevilla y Ayuntamiento de Carmona, 2003, pp. 85-118.

Mármol Carvajal, Luis del, Rebelión y castigo de los moriscos, Málaga, Editorial Arguval, 1991.

Martín Casares, Aurelia, La esclavitud en la Granada del siglo XVI, Granada, Universidad, 2000.

Martz, Linda y Porres Martín-Cleto, Julio, Toledo y los toledanos en 1561, Toledo, CSIC, 1974.

Memorias y sucesos notables de Europa, especialmente de Aracena y de sus inmediaciones (Anales de 1558-1611), edición y estudio de Javier PérezEmbid, Huelva, Diputación, 1999.

Navas Acosta, Antonio, "La batalla de Frigiliana o la rebelión de Bentomiz", Jábega, 9 (1975), pp. 17-26.

Pereiro Barbero, Presentación, "Notas sobre población y urbanismo de la Axarquía. La incidencia de la guerra de Granada (1568)", en Andalucía en el tránsito a la modernidad. Actas del Coloquio celebrado con motivo del $V$ Centenario de la conquista de Vélez-Málaga (1487-1987), Málaga, Diputación, pp. 79-93.

Pérez García, Rafael M. y Fernández Chaves, Manuel F., "La infancia morisca, entre la educación y la explotación”, en Francisco Núñez Roldán (ed.), La 
infancia en España y Portugal. Siglos XVI-XIX, Madrid, Sílex, 2011, pp. 149-186.

Prieto Bernabé, José Manuel, "Los moriscos en Pastrana según el censo de 1573”, I Congreso de Historia de Castilla-La Mancha, Toledo, Junta de Comunidades de Castilla-La Mancha, 1988, tomo VII, pp. 269-282.

Rabasco Valdés, José Manuel, "Dos aspectos de la esclavitud morisca. Málaga, 1569”, Homenaje al Dr. D. Juan Reglà Campistol, Valencia, Universidad, 1975, vol. I, pp. 293-302.

Resa Moncayo, Francisco Javier, "Realidad morisca en Antequera (1560-1585)", en Antonio Mestre Sanchís y Enrique Giménez López (coords.), Disidencias y exilios en la España moderna (Actas de la IV Reunión Científica de la Asociación Española de Historia Moderna), Alicante, 1997, tomo II, p. 423 433.

Rodríguez de Gracia, Hilario, "Moriscos expulsados de Granada y 'avecindados' en Toledo", Hispania Sacra, 65, Extra I (2013), pp. 153-188.

Ruiz Pérez, Antonio, "El levantamiento morisco en tierras de señorío. El caso del marquesado de Cenete", Chronica Nova, 19 (1991), pp. 291-336.

Sánchez Ramos, Valeriano, "Los tercios de Italia y la guerra de los moriscos", en Manuel Barrios Aguilera y Ángel Galán Sánchez (ed.), La Historia del Reino de Granada a debate. Viejos y nuevos temas. Perspectivas de estudio, Málaga, Diputación, 2004, pp. 77-112.

Tapia Garrido, José Ángel, Historia de la Baja Alpujarra, Almería, Ayuntamientos de Adra, Berja, Dalías, El Ejido e Instituto de Estudios Almerienses, 1989.

Vincent, Bernard, "Los moriscos granadinos: ¿una frontera interior?”, El río morisco, Valencia, Universitat, 2006, pp. 163-185.

Vincent, Bernard, "Guerra y hábitat en Andalucía oriental en el siglo XVI", El río morisco, Valencia, Universitat, 2006, pp. 119-130.

Vincent, Bernard, "La expulsión de los moriscos del Reino de Castilla y su reparto en Castilla", en Bernard Vincent, Andalucía en la Edad Moderna: economía y sociedad, Granada, Diputación, 1985, pp. 215-266.

Vincent, Bernard, “¿Cuál era el aspecto físico de los moriscos?”, Andalucía en la Edad Moderna: economía y sociedad, Granada, Diputación, 1985, pp. 303313.

Vincent, Bernard, "Economía y sociedad en el Reino de Granada", en Antonio Domínguez Ortiz (dir.), Historia de Andalucía, Madrid, Planeta, 1983, vol. IV, pp. 161-223.

Recibido: $24 / 11 / 2014$

Aceptado:12/02/2016 